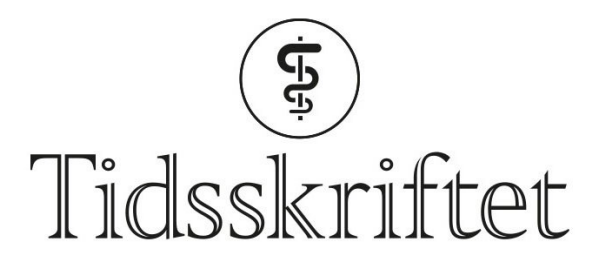

DEN NORSKE LEGEFORENING

\title{
Vern til pasientenes verste?
}

REDAKSJONELL KOMMENTAR

\section{RAGNHILD ØRSTAVIK}

E-post: ragnhild.orstavik@tidsskriftet.no

Ragnhild Ørstavik er assisterende sjefredaktør i Tidsskriftet. Hun er dr.med. og har en bistilling som seniorforsker ved Folkehelseinstituttet.

Den pågående debatten om personvern og pasientsikkerhet viser at vi i tillegg til sikre systemer for personvern trenger sikre systemer for tolkning av lovverket.

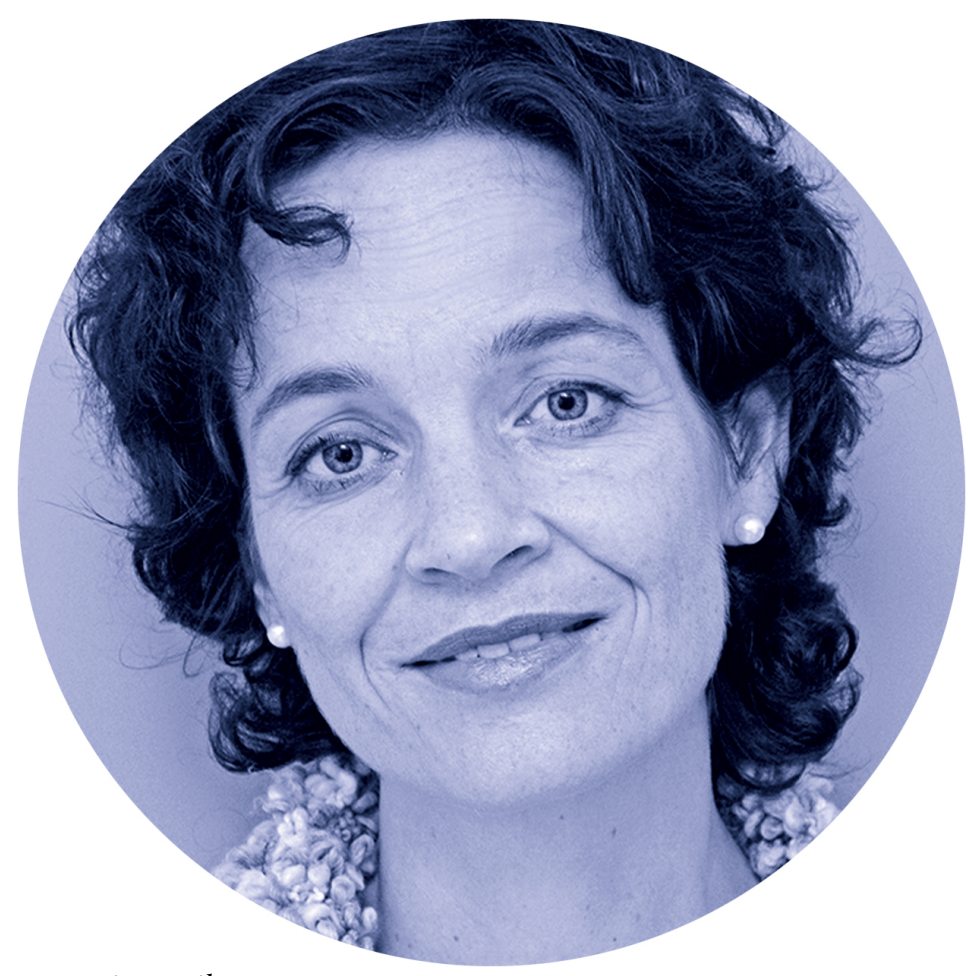

Foto: Einar Nilsen

Under overskriften «Dødelig personvern» skrev Torkel Steen i Aftenposten 19.12.2018 om hvordan hensynet til personvernet hindrer ham og andre helsearbeidere i å utføre arbeidet sitt til det de mener er det beste for nåværende - og kommende - pasienter (1): IT-løsninger godkjent av EU er ikke sikre nok for Norge. Pasientopplysninger kan ikke sendes elektronisk i akuttsituasjoner. Leger som logger seg inn i journalen for å sjekke om behandlingen de ga i mottaket førte til bedring eller $\mathrm{d} ø \mathrm{~d}$, bryter sykehusets interne regelverk dersom pasienten ikke eksplisitt har gitt sitt samtykke til innsyn (1).

Helseminister Bernt Høie svarte Steen 27.12.2018, og forklarte blant annet at legene ikke bryter loven i det siste tilfellet dersom pasienten ikke eksplisitt har sagt at han eller hun 
ikke ønsker at den aktuelle legen skal få tilgang til journalen (2). Uttalelsen er verdt å dvele ved. Helsepersonelloven paragraf 29c, som Høie henviser til, sier: «Med mindre pasienten motsetter seg det, kan taushetsbelagte opplysninger etter særskilt anmodning gjøres tilgjengelige for annet helsepersonell som tidligere har ytt helsehjelp til pasienten i et konkret behandlingsforløp, for kvalitetssikring av helsehjelpen eller egen læring. Behandlingen av anmodningen kan automatiseres. (...)»

Det er selvsagt stor forskjell mellom å måtte innhente samtykke fra pasienten for å slå opp i journalen, og å la det være i de (sannsynligvis ytterst sjeldne) tilfellene pasienten på eget initiativ har motsatt seg dette (dersom ikke alle pasienter som akuttinnlegges ved Oslo universitetssykehus bes om å samtykke). I sitt svar konkluderer Steen forståelig nok med at Oslo universitetssykehus har tolket loven for strengt (3). Dette belyser et kjernepunkt i hva dette handler om: Tolkning av lovverket, med de konsekvenser det får for pasientenes behandling og legenes læring, overlates til de enkelte institusjonene og deres personvernombud.

Dette er bare ett av mange eksempler på at interne tolkninger av personvern styrer institusjonenes pasientbehandling, kvalitetssikring, undervisning og - ikke minst forskning $(4,5)$. Personvernombudene har en sentral rolle, men de er, slik Datatilsynet beskriver det, rådgivende (6). Det er på høy tid at ledelsen ved landets sykehus, sammen med relevante tilsyn og politikere, ser på hvordan lovene skal tolkes og personvern utøves i praksis. Det viktigste må være at vernet er til dagens og fremtidens pasienters beste.

\section{LITTERATUR:}

1. Steen T. Dødelig personvern. Aftenposten 18.12.2018. https://www.aftenposten.no/meninger/debatt/i/VR7jEW/Dodelig-personvern-Torkel-Steen (7.1.2019).

2. Høie B. Pasientsikkerhet krever ikke lovbrudd. Aftenposten 27.12.2018.

https://www.aftenposten.no/meninger/debatt/i/m6bj8q/Pasientsikkerhet-krever-ikke-lovbrudd-BentHoie (7.1.2019).

3. Steen T. Helseministeren bør lytte mer til de som faktisk leverer helsetjenestene. Aftenposten 3.1.2019.

https://www.aftenposten.no/meninger/debatt/i/VRnb1W/Helseministeren-bor-lytte-mindre-til-byrakr atene-og-mer-til-de-som-faktisk-leverer-helsetjenestene-Torkel-Steen?fbclidIwAR3gvAgZ1E86VIknhlyaVEOZsu1YsFzzo74ivipJoiflOLuE2oW8J6C41w (7.1.2019).

4. Westerveld J, Dommerud T, Torseth NS. 32 leger gjør opprør: Strengt personvern rammer pasientene. Aftenposten 7.1.2019.

https://www.aftenposten.no/norge/i/kagngQ/32-leger-gjor-oppror-Strengt-personvern-rammer-pasien tene (7.1.2019).

5. Lund-Johansen F, Brinchmann JE, Vaage JT et al. Når personvern truer folkehelsen. Aftenposten 7.1.2019.

https://www.aftenposten.no/meninger/debatt/i/VRnber/Nar-personvern-truer-folkehelsen-32-forsker e-ved-Oslo-universitetssykehus (7.1.2019).

6. Datatilsynet. Personvernombud.

https://www.datatilsynet.no/rettigheter-og-plikter/virksomhetenes-plikter/personvernombud/ (7.1.2019).

Publisert: 7. januar 2019. Tidsskr Nor Legeforen. DOI: 10.4045/tidsskr.19.0029

(C) Tidsskrift for Den norske legeforening 2020. Lastet ned fra tidsskriftet.no 